\title{
Self-Care Program for Improving the Daily Stressors of Osteoarthritic Elderly Patients Residents of Elderly Homes in Port Said City
}

Prof. Nawal Mahmoud Soliman ;Prof. Hassan Ali Abd ElWahed ; Dr. Reda Ibrahim El-Mowafy ;Dr. Omaima Mohamed EL-Alem ;Fatma Mohamed Mohamed El-Swerky Prof of Community Health Nursing, Faculty of Nursing, Ain Shams University; Prof of Family Medicine, Faculty of Medicine, Suez Canal University; Lecturer of family and Community Health Nursing, Faculty of Nursing, Port Said University; Lecturer of Family and Community Health Nursing, Faculty of Nursing, Port Said University; Assistant Lecturer in Family and Community Health Nursing, Faculty of Nursing, Port Said University.

\begin{abstract}
Background: Elders living with osteoarthritis perceive many chronic daily stressors along with a loss of function, diminished independence, and the progression of an illness without a cure .Aims of This study: was to evaluate the effect of self-care program for improving the daily stressors of osteoarthritic elderly patients residents in elderly homes in Port Said City. Design quasi-experimental study. Sample the study was conducted on 42 elders having the inclusion criteria. Setting this study was implemented in all geriatric homes in Port Said city (namely: Dar El-Hanan, Dar El-Takreem, and Dar Mubarak). Tools: the first tool part (I): Socio-demographic characteristics of the studied elders. Part (II): Medical history of osteoarthritic elderly patients, Part (III): Health Assessment Questionnaire Disability Index, Part (IV): Depression Scale, Part (V): The Arthritis Self-efficacy Scale, Part (VI): osteoarthritis related stressors checklist (part VII): Self-care program. The second tool (2): Anthropometric Measurement. Tools were used pre, post program and after 3 months. Result the effect of the program was positive in improving functional abilities, depressed mood, and self-efficacy of the osteoarthritic elderly patients immediately after its implementation but to a lesser value after 3 months with a statistical significant. Conclusion Based on the results of the present study and research hypotheses it can concluded that the implementation of the self-care program for osteoarthritic elders is associated with significant improvements in their functional abilities, depressed mood, and self- efficacy. Recommendations broader implementation of self-care management model in elderly homes could reduce the significant current and projected burden of the disease as well as improve self- care in institutionalized elders.
\end{abstract}

Keywords: Osteoarthritis, Self-care program, Elders, Daily stress 


\section{INTRODUCTION}

Osteoarthritis is a leading cause of disability, which threats all aspects of elders' life, (Smeltzer et al., 2008), a sit often deprives them of their freedom and independence as well as it can disrupt the lives of family members and other caregivers (Cook et al., 2007). Elders with osteoarthritis usually experience pessimism and distressing feeling as consequence of the pain and difficulty in daily activities (NHS, 2008). These typically result in more visits to the clinician's office, less expression of emotion, more pain, and more depression (Weaseling, 2013). In general, individuals with osteoarthritis report lower level of quality of life and a negative perception of life compared to individuals without osteoarthritis, (Giqnac et al. 2006; Cook et al., 2007). This might in Part be due to difficulties and frustration of not being able to manage the disease, especially the pain and disability.

Elders living with osteoarthritis perceive many chronic daily stressors along with a loss of function, diminished independence, and the progression of an illness without a cure, chronic daily stressors and hassles, acting cumulatively and mediating the effects of life events, have significant impacts on health outcomes and are related to physical disability, psychological health, and pain among older people with osteoarthritis. Sedentary elders with osteoarthritis often find it difficult to perform even simple daily activities such as reaching into overhead cabinets, shopping, cleaning house, and walking up and down stairs, which are very strong predicators of loss of functional independence (Almeida 2005). Inactivity also leads to increased risk of falls and fracture, depressed mood, social isolation, decrease functional ability, dependency, and eventually institutionalization (Carol 2012).

Self-car program support the leading role of elderly patients managing their chronic conditions by teaching elders with osteoarthritis the methods of adapting new perspective and generic skills in problem solving and practicing healthier lifestyle and behaviors. It provides information about general principles needed by the individual to take care of themselves. In particular for osteoarthritis, it provide information regarding the nature of osteoarthritis, pain management, exercise, energy conservation, joint protection, depression, medication, nutrition, sleep, family relationships, stress and relaxation, and working with health professionals,(Newman et al., 2005).

\section{Significance of the study:}

Because of the increasing proportion of the aging population in Egypt, there is an urgent need for a comprehensive and evidence-based prevention strategy for osteoarthritis pain and disability. However few prospective longitudinal studies have been undertaken and little information is available regarding the prevalence and incidence of osteoarthritis. The extrapolated statistical estimated the burden of osteoarthritis in Egypt in 2010 as about 6 million cases out of 80 million population. 


\section{Aim of Study:}

The aim of this study is to evaluate the effect of self-care program for improving the daily stressors of osteoarthritic elderly patient residents in elderly homes in Port Said city.

\section{Research Hypotheses:}

1. It was hypothesized that the program portrayed in the current study would be succeed in increasing skills performance and self -care practices of the osteoarthritis elderly patients as evidence by improvement in their depressed mood, functional abilities, self- efficacy, and disease related stressors post self -care program.

2. There is a difference between male and female in the experience of depressed moode caused by osteoarthritis

\section{SUBJECT AND METHODS:}

\section{Research Design:}

Quasi-experimental research design.

\section{Setting:}

The present study implemented in all geriatric homes in Port Said city (namely: Dar El-Hanan, Dar El-Takreem, and Dar Mubarak).

\section{Sample:}

Purposive sample used in this study comprise all the elderly patients of both sexes with osteoarthritis (OA) residing in the above setting, their number amounted to $\mathbf{4 2}$ elderly patients and fulfilling the following including criteria:

1. Age 60 years and above.

2. Diagnosed with osteoarthritis (OA) for more than one year.

3. Absence of any other rheumatic disease or any associated disorder that can affect elder's physical ability such as stroke, fracture, or trauma.

4. Able to communicate and comprehend effectively.

5. Agree to participate in the study.

\section{Tools of data collection:}

The data was collected by using the following tools:

TOOL (1): An interview questionnaire was used to collect data of this study it contains the following parts:

Part (1): Socio-demographic characteristics of the studied elders.

Part (2): Medical history of osteoarthritis elderly patients.

TOOL (2): Health assessment questionnaire disability index HAQ-DI; developed by Fries (1980).

TOOL (3): center for epidemiological studies depression scale CES-D; developed by Lenore Radloff (1977). 
TOOL (4): The arthritis self-efficacy scale ASES; developed by Lorig (1989).

TOOL (5): osteoarthritis related stressors checklist, developed by Waltz (1991), and revised by Mahat (1997)

\section{TOOL (6): Anthropometric Measurement.}

The elderly patient's BMI was compared with body mass index chart.

\section{Content Validity:}

- $\quad$ Tool (I) part (I, II) structure interview sheet) and tool 2 (Anthropometric measurement) were developed by the researcher after thorough review of literature.

- $\quad$ parts from III to VI were translated into Arabic by the researcher, and tested for the content validity of the tools were tested by a jury of 9 experts in the related fields of community and family nursing, medical surgical nursing and family medicine, the required corrections and modifications were carried out accordingly.

\section{Pilot Study:}

A pilot study was carried out on $10 \%$ (5 elders) of the study subjects to test the tools before starting the data collection, and they were not be excluded from the entire sample of research work. The purposes of the pilot study are to test the applicability and clarify the feasibility of the study tools, and it severed to estimate the time needed to complete the tools, it also helped to find out any obstacles and problems that might interfere with data collection based on the findings of the pilot study. The necessary modifications were done and the sheets were put in the final form.

\section{Reliability:}

The reliability of all tools from III to VI was done using test - retest, this was done through administration of these tools to elderly patients with osteoarthritis residing in Dar El-Hanan, Dar El-Takreem and Dar Mubarak. The scales were applied again for the same elderly patients after two weeks. The reliability was assured by means of Cronbach's it indicated that the health assessment questionnaire disability index, center for Epidemiological studies depression scale, arthritis self - efficacy scale, and related stressors checklist have reliabilities of $0.82,0.91,0.87$ and 0.94 respectively.

\section{Field Work:}

- Pretest was done for all elderly patients with osteoarthritis (OA) who residents of elderly homes in Port-Said according to inclusion criteria who were 42 elderly patients and the data was collected by the researcher using the constructed tools through the personal interview.

- Subject was informed about the purpose of the study.

- The subject consent was taken, they were informed about their right to not be taken against them, and it was used for the purpose of the study.

- The pretest was done at the beginning of January 2013.

- The preparation of the program took 8 weeks. 
- The program implementation started from the first of Mars to the half of April, after 3 months (as follow- up of the program), and 4 weeks for follow-up test.

- An introduction was given by modified lecture at the beginning of each day followed by class discussion and data show, using power point pictures

\section{Self - care Program was carries out through the following phases:}

\section{Phase (1): Preparatory Phase}

The content of the intervention program is developed by the researcher after thorough review of literature, and assessing of osteoarthritic elders' self -care practice, functional abilities, depressed mood, self- efficacy, disease related stressors and daily living activities.

\section{Phase (2): The planning Phase}

Self- care program was developed by researcher after reviewing of the related literature. To supply the resident elders with osteoarthritis of the different strategies of self-care program to improve the daily living stressors associated with osteoarthritis. The program was prepared and divided into 12 sessions. After preparing self- care program, it was reviewing by two specialists in the related fields as community and family health nursing. Their instructions were followed in order to correct and put the program into the final form. Before starting self care program, each person in the recruited subjects were interviewed individually to complete tools from III to VI.

\section{Phase (3): Implementation Phase}

The self- care program was implemented on group bases divided into 6 groups; each group consisted of 7 elders. The elders participated in about half to one hour self- care session (according to the activities required in each session to be achieved and attention span of the elders), two times per weeks for a month and a half (from the first of Mars to the half of April). The total number of sessions was 12 sessions; the researcher visited two groups per day. the program focused on teaching participants how to cope with and manage common osteoarthritis stressors ad consequences, such as pain, fatigue, daily activity limitations and stress. It was designed to give elderly participants skills they could use to optimize their ability to manage their condition.

- Teaching methods included lectures, group discussion, role-playing, brainstorming demonstration and redemonstration, models, pictures, real life demonstration, problems solving, and mastery experience (i.e., trying out the skills introduced on the self- care program).

- Handout about exercise, use of assistive devices, joint protection and energy conservation techniques were given to the participants to guide and enrich their memory about the activities performed in each session.

- Action plan calendar was prepared and given to each participant, it included what, how much, when and how many days a week the elder is supposed to practice the taught activities in order to master them. 


\section{The following topics were included in the program:}

1. Basic information about osteoarthritis.

2. Importance of self- care practices.

3. Problem solving approaches (ways of energy conservation).

4. Pain management techniques.

5. Nutrition and pharmacological treatment.

6. Exercise.

7. Use of assistive devices.

8. Communication with family and health professionals.

9. Dealing with emotional disturbances associated with osteoarthritis.

\section{Evaluation Phase}

- After the implementation of the self-care program, each elder was reassessed immediately then after three months later to evaluate the effect of the program on his / her functional abilities, depressed mood, self-efficacy, and the disease related stressor both on short and long term basis using the study tool (Tool II to Tool VI).

- The total period of data collection (since entitle assessment to evaluation) covered a period of six months.

\section{RESULTS:}

Table (1): Shows that the main age of elders was $68.82 \pm 5.6$ years, $57.1 \%$ of osteoarthritic elderly patients were female and the rest $42.9 \%$ were male. The majority of elders $57.1 \%$ were widow, illiteracy was reported by $40.5 \%$ of the subjects, those with either primary or preparatory education, and secondary or higher education amounted to $35.7 \%$ and $14.3 \%$ respectively, $38.1 \%$ were housewife and $23.8 \%$ were technical worker.

Table (2): Shows that only $19.0 \%$ of the subjects practice exercises while the rest didn't, females were observed to have a sedentary life $91.7 \%$ compared to $66.7 \%$ of the males. The most common causes of not practicing exercise were their beliefs that exercise is in effective $76.5 \%$, or it increases pain $73.5 \%$, or accelerate the progression of the disease $47.0 \%$. All the barriers were reported more frequently by females compared to the males.

Table (3): Represents that $71.1 \%$ of elders did not believe in the importance of diet management for osteoarthritis, $52.4 \%$ of non-complaint elder reported their functional disabilities to hamper their compliance. Lack of information regarding diet management was reported by $57.1 \%$ of the non-complaint elders. Reasons of nonadherence to dietary management were reported too much higher percent of female group compared to male one. Only $26.3 \%$ of the studied elderly patients followed diet planning for weight reduction.

Table (4): Shows that stressors experienced by the elderly patients varied in comparing preprogram to post program and three months later. The main stressors 
were successfully decreasing as reported by the patients immediately after the program and increased slightly again three months later; such as pain, difficulty of movement, and difficulty in daily activities. Some stressors were increasingly reported by the patient immediately after the program compared to before for both male and female patients, and dropped again after three months; like difficulty in social activity, problems in family relations difficulties performing at work, and discomfort of treatment.

Table (5): indicates that there is a significant improvement in the depressed moodof the male and female osteoarthritic elders after the implementation of the self-care program which decreased again three months later but with a significant difference compared to the pre-program period. No statistical difference between two groups in the post program and three evaluation program $(\mathrm{P}=0.486$ and $\mathrm{P}=0.455$ respectively).

Table (6): Shows that there is a significant improvement in the functional abilities of the male and female osteoarthritic elderly patients immediately after the implementation of the self-care program and 3 months later. Although the mean score showed better improvement in the male group than the female group, the different were statistically significant three months later $(\mathrm{P}=0.032)$.

Table (7): Illustrates that male patients with low self-efficacy decreased to just two cases $11.1 \%$ immediate after the program and three months later. Just one case of females had low self-efficacy immediate after the program $4.2 \%$ compared to before the program, the figure which increased to $8.3 \%$ three months later. 
Table (1): Distribution of the osteoarthritic elders according to their sociodemographic characteristics.

\begin{tabular}{|l|c|c|}
\hline \multirow{2}{*}{ Socio-demographic characteristics } & \multicolumn{2}{c|}{ No. of elders } \\
(n=42)
\end{tabular}

\# 4 females were employees, 4 were technical workers and 3 were commercial workers.

Table (2): Distribution of the male and female osteoarthritic elderly patients according to their practice of exercise.

\begin{tabular}{|c|c|c|c|c|c|c|c|}
\hline \multirow{2}{*}{ Practice exercise } & \multicolumn{2}{|c|}{ Male } & \multicolumn{2}{|c|}{ Female } & \multicolumn{2}{|c|}{ Total } & \multirow{2}{*}{$\begin{array}{c}\text { Test of } \\
\text { significance }\end{array}$} \\
\hline & No & $\%$ & No & $\%$ & No & $\%$ & \\
\hline Practice exercise: & \multicolumn{2}{|c|}{$N=18$} & \multicolumn{2}{|c|}{$\mathrm{N}=24$} & \multicolumn{2}{|c|}{$\mathrm{N}=42$} & \multirow{3}{*}{$\begin{array}{c}\mathrm{X}^{2}=3.817 \\
\mathrm{P}=0.143\end{array}$} \\
\hline No & 12 & 66.7 & 22 & 91.7 & 34 & 81.0 & \\
\hline Yes & 6 & 33.3 & 2 & 8.3 & 8 & 19.0 & \\
\hline Cause of non-compliance: \# & \multicolumn{2}{|c|}{$N=12$} & \multicolumn{2}{|c|}{$\mathbf{N}=\mathbf{2 2}$} & \multicolumn{2}{|c|}{$\mathbf{N}=\mathbf{3 4}$} & \multirow{5}{*}{$\begin{aligned} \mathrm{X}^{2} & =4.301^{*} \\
\mathrm{P} & =0.031\end{aligned}$} \\
\hline Ineffective & 8 & 66.7 & 18 & 81.8 & 26 & 76.5 & \\
\hline Increases pain & 11 & 91.7 & 14 & 63.6 & 25 & 73.5 & \\
\hline Accelerates disease progression & 5 & 41.7 & 9 & 40.9 & 14 & 41.2 & \\
\hline Didn't know type of exercise & 6 & 50.0 & 10 & 45.5 & 16 & 47.0 & \\
\hline
\end{tabular}

\# More than one answer was given by the elderly patients *: Statistically significant at $P \leq 0.05$ 
Table (3): Distribution of the male and female osteoarthritic elderly patients according to their diet management.

\begin{tabular}{|c|c|c|c|c|c|c|c|}
\hline \multirow{2}{*}{ Diet management } & \multicolumn{2}{|c|}{ Male } & \multicolumn{2}{|c|}{ Female } & \multicolumn{2}{|c|}{ Total } & \multirow{2}{*}{$\begin{array}{c}\text { Test of } \\
\text { significance }\end{array}$} \\
\hline & No & $\%$ & No & $\%$ & No & $\%$ & \\
\hline $\begin{array}{l}\text { Compliance with dietary } \\
\text { management }\end{array}$ & \multicolumn{2}{|c|}{$(n=18)$} & \multicolumn{2}{|c|}{$(n=24)$} & \multicolumn{2}{|c|}{$(n=42)$} & \multirow{3}{*}{$\begin{aligned} \mathrm{X}^{2} & =5.503^{*} \\
\mathrm{P} & =0.001\end{aligned}$} \\
\hline No & 6 & 33.3 & 15 & 62.5 & 21 & 50 & \\
\hline Yes & 12 & 66.7 & 9 & 34.3 & 21 & 50 & \\
\hline Cause of non-compliance: \# & \multicolumn{2}{|c|}{$\mathrm{N}=6$} & \multicolumn{2}{|c|}{$\mathrm{N}=15$} & \multicolumn{2}{|c|}{$\mathbf{N}=\mathbf{2 1}$} & \multirow{4}{*}{$\mathrm{FEP}=0.003 *$} \\
\hline Ineffective & 3 & 50.0 & 12 & 80 & 15 & 71 & \\
\hline Functional disabilities & 2 & 33.3 & 9 & 60 & 11 & 52.4 & \\
\hline Lack of information & 2 & 33.3 & 10 & 66.7 & 12 & 57.1 & \\
\hline \multirow{2}{*}{$\begin{array}{l}\text { Diet planning for weight } \\
\text { reduction }\end{array}$} & \multicolumn{2}{|c|}{$(n=18)$} & \multicolumn{2}{|c|}{$(\mathrm{n}=24)$} & \multicolumn{2}{|c|}{$(n=42)$} & $\mathrm{X}^{2}=2.101$ \\
\hline & 6 & 33.3 & 5 & 20.8 & 11 & 26.2 & $\mathrm{P}=0.351$ \\
\hline
\end{tabular}

\# More than one cause reported by the elderly patients *: Statistically significant at $P \leq 0.05$

Table (4): OA related stressors in carrying out the activities of daily living of the male and female elderly patients before and after the implementation of self-care program (immediate and three months later).

\begin{tabular}{|c|c|c|c|c|c|c|c|c|c|c|c|c|}
\hline \multirow{3}{*}{ OA related stressors } & \multicolumn{4}{|c|}{ Before the Program } & \multicolumn{4}{|c|}{$\begin{array}{c}\text { Immediately after the } \\
\text { Program }\end{array}$} & \multicolumn{4}{|c|}{ Three Months Later } \\
\hline & \multicolumn{2}{|c|}{$\begin{array}{c}\text { Male } \\
(n=18)\end{array}$} & \multicolumn{2}{|c|}{$\begin{array}{c}\text { Female } \\
(n=24)\end{array}$} & \multicolumn{2}{|c|}{$\begin{array}{c}\text { Male } \\
(n=18)\end{array}$} & \multicolumn{2}{|c|}{$\begin{array}{c}\text { Female } \\
(n=24)\end{array}$} & \multicolumn{2}{|c|}{$\begin{array}{c}\text { Male } \\
(n=18)\end{array}$} & \multicolumn{2}{|c|}{$\begin{array}{c}\text { Female } \\
(\mathbf{n}=24)\end{array}$} \\
\hline & No & $\%$ & No & $\%$ & No & $\%$ & No & $\%$ & No & $\%$ & No & $\%$ \\
\hline $\begin{array}{l}\text { Difficulties in } \\
\text { carrying out ADL }\end{array}$ & 9 & 50.0 & 12 & 50.0 & 5 & 27.8 & 9 & 37.5 & 6 & 33.3 & 11 & 45.8 \\
\hline Pain & 8 & 44.4 & 15 & 62.5 & 4 & 22.2 & 9 & 37.5 & 5 & 27.8 & 10 & 41.7 \\
\hline $\begin{array}{l}\text { Limitation in } \\
\text { mobility }\end{array}$ & 5 & 27.8 & 10 & 41.7 & 4 & 22.2 & 7 & 29.2 & 5 & 27.8 & 8 & 33.3 \\
\hline Helplessness & 5 & 27.8 & 5 & 20.8 & 3 & 16.7 & 3 & 12.5 & 3 & 16.7 & 4 & 16.7 \\
\hline $\begin{array}{l}\text { Dependency on } \\
\text { others }\end{array}$ & 5 & 27.8 & 4 & 16.7 & 2 & 11.1 & 2 & 8.3 & 3 & 16.7 & 4 & 16.7 \\
\hline $\begin{array}{l}\text { Interference in } \\
\text { family relationship }\end{array}$ & 4 & 22.2 & 3 & 12.5 & 6 & 33.3 & 7 & 29.2 & 3 & 16.7 & 5 & 20.8 \\
\hline $\begin{array}{l}\text { Discomfort of } \\
\text { treatment }\end{array}$ & 1 & 5.6 & 2 & 8.3 & 6 & 33.3 & 8 & 33.3 & 4 & 22.2 & 6 & 25.0 \\
\hline $\begin{array}{l}\text { Interference in social } \\
\text { activity }\end{array}$ & 1 & 5.6 & 1 & 4.2 & 3 & 16.7 & 4 & 16.7 & 2 & 11.1 & 2 & 8.3 \\
\hline Threat to self esteem & 0 & 0.0 & 2 & 8.3 & 1 & 6.5 & 3 & 12.5 & 3 & 16.7 & 3 & 12.5 \\
\hline $\begin{array}{l}\text { Difficulties } \\
\text { performing at work }\end{array}$ & 1 & 5.6 & 0 & 0.0 & 3 & 16.7 & 0 & 0.0 & 1 & 5.6 & 0 & 0.0 \\
\hline
\end{tabular}


Table (5): Depressed mood of the male and female osteoarthritic elderly patient before and after the implementation of self-care program (immediate and three months later)

\begin{tabular}{|c|c|c|c|c|c|c|c|c|c|c|c|c|}
\hline \multirow{3}{*}{ Depressed moods } & \multicolumn{4}{|c|}{ Before the Program } & \multicolumn{4}{|c|}{$\begin{array}{c}\text { Immediately after the } \\
\text { Program }\end{array}$} & \multicolumn{4}{|c|}{ Three Months Later } \\
\hline & \multicolumn{2}{|c|}{$\begin{array}{c}\text { Male } \\
(n=18)\end{array}$} & \multicolumn{2}{|c|}{$\begin{array}{c}\text { Female } \\
(\mathbf{n}=24)\end{array}$} & \multicolumn{2}{|c|}{$\begin{array}{c}\text { Male } \\
(n=18)\end{array}$} & \multicolumn{2}{|c|}{$\begin{array}{c}\text { Female } \\
(\mathbf{n}=24)\end{array}$} & \multicolumn{2}{|c|}{$\begin{array}{c}\text { Male } \\
(n=18)\end{array}$} & \multicolumn{2}{|c|}{$\begin{array}{c}\text { Female } \\
(\mathbf{n}=24)\end{array}$} \\
\hline & No & $\%$ & No & $\%$ & No & $\%$ & No & $\%$ & No & $\%$ & No & $\%$ \\
\hline Non-depressed & 7 & 38.9 & 5 & 20.8 & 14 & 77.8 & 19 & 79.2 & 10 & 55.6 & 14 & 58.3 \\
\hline Depressed & 11 & 61.1 & 19 & 79.2 & 4 & 22.2 & 5 & 20.8 & 8 & 44.4 & 10 & 41.7 \\
\hline FEP & \multicolumn{4}{|c|}{0.723} & \multicolumn{4}{|c|}{$0.053^{*}$} & \multicolumn{4}{|c|}{0.371} \\
\hline Mean \pm SD & 1.2 & 0.46 & & $=0.37$ & 1.13 & 0.37 & & 0.28 & 1.27 & 0.48 & 1.3 & 0.27 \\
\hline$-\mathbf{t}(\mathbf{P})$ & \multicolumn{4}{|c|}{$0.730(0.393)$} & \multicolumn{4}{|c|}{$0.716(0.486)$} & \multicolumn{4}{|c|}{$0.704(0.455)$} \\
\hline$-\mathbf{t}_{1}(\mathbf{P})$ & & & & & \multicolumn{2}{|c|}{$\begin{array}{c}2.519 \\
(0.032)^{*}\end{array}$} & \multicolumn{2}{|c|}{$\begin{array}{c}3.435 \\
(0.001)^{*} \\
\end{array}$} & \multicolumn{2}{|c|}{$\begin{array}{c}2.889 \\
(0.009)^{*}\end{array}$} & \multicolumn{2}{|c|}{$\begin{array}{c}2.772 \\
(0.013)^{*}\end{array}$} \\
\hline$-\mathbf{t}_{2}(\mathbf{P})$ & & & & & & & & & & & & \\
\hline
\end{tabular}

\section{t: Student t-test}

FEP: $P$ value for fisher exact test.

$t_{1}$ : Paired t-test between before the program and other periods.

$t_{2}$ : Paired t-test between immediately after the program and three month later.

*: Statistically significant at $P<0.05$

Table (6): Functional abilities of the male and female osteoarthritic elderly patients before and after the implementation of self-care program (immediate and three months later).

\begin{tabular}{|c|c|c|c|c|c|c|c|c|c|c|c|c|}
\hline \multirow{3}{*}{$\begin{array}{c}\text { Levels of Functional } \\
\text { Abilities }\end{array}$} & \multicolumn{4}{|c|}{ Before the Program } & \multicolumn{4}{|c|}{$\begin{array}{c}\text { Immediately after the } \\
\text { Program }\end{array}$} & \multicolumn{4}{|c|}{ Three Months Later } \\
\hline & \multicolumn{2}{|c|}{$\begin{array}{c}\text { Male } \\
(\mathrm{n}=18)\end{array}$} & \multicolumn{2}{|c|}{$\begin{array}{c}\text { Female } \\
(n=24)\end{array}$} & \multicolumn{2}{|c|}{$\begin{array}{c}\text { Male } \\
(\mathrm{n}=18)\end{array}$} & \multicolumn{2}{|c|}{$\begin{array}{c}\text { Female } \\
(n=24)\end{array}$} & \multicolumn{2}{|c|}{$\begin{array}{c}\text { Male } \\
(\mathrm{n}=18)\end{array}$} & \multicolumn{2}{|c|}{$\begin{array}{c}\text { Female } \\
(n=24)\end{array}$} \\
\hline & No & $\%$ & No & $\%$ & No & $\%$ & No & $\%$ & No & $\%$ & No & $\%$ \\
\hline Mild disability & 5 & 27.8 & 5 & 20.8 & 12 & 66.7 & 9 & 37.5 & 9 & 50.0 & 7 & 29.2 \\
\hline Moderate disability & 9 & 50.0 & 6 & 25.0 & 5 & 27.8 & 12 & 50.0 & 7 & 38.9 & 11 & 45.8 \\
\hline Severe disability & 4 & 22.2 & 13 & 54.2 & 1 & 5.5 & 3 & 12.5 & 2 & 11.1 & 6 & 25.0 \\
\hline Test of sig. & \multicolumn{4}{|c|}{$\mathrm{X}^{2}=5.003, \mathrm{P}=0.025^{*}$} & \multicolumn{4}{|c|}{$\mathrm{MCP}=0.407$} & \multicolumn{4}{|c|}{$\mathrm{X}^{2}=1.593, \mathrm{P}=0.456$} \\
\hline Mean \pm SD & \multicolumn{2}{|c|}{$58 \pm 0.23$} & \multicolumn{2}{|c|}{$1.85 \pm 0.620$} & \multicolumn{2}{|c|}{0.420} & \multirow{2}{*}{\multicolumn{2}{|c|}{$\frac{0.97}{352)}$}} & \multicolumn{2}{|c|}{$.09 \pm 0.66$} & \multicolumn{2}{|c|}{$1.26 \pm$} \\
\hline $\mathbf{t}(\mathbf{P})$ & \multicolumn{4}{|c|}{$2.426(0.035)^{*}$} & \multicolumn{2}{|c|}{$0.984(0.352)$} & & & \multicolumn{4}{|c|}{$2.121(0.032)^{*}$} \\
\hline$t_{1}(\mathbf{P})$ & & & & & \multicolumn{2}{|c|}{$\begin{array}{c}8.005 \\
(<0.001)^{*}\end{array}$} & \multicolumn{2}{|c|}{$\begin{array}{c}8.333 \\
(<0.001)^{*}\end{array}$} & & & \multicolumn{2}{|c|}{$\begin{array}{c}5.603 \\
(0.001) *\end{array}$} \\
\hline $\mathbf{t}_{2}(\mathbf{P})$ & & & & & & & & & $\begin{array}{r}6 \\
(<0 \\
\end{array}$ & $\begin{array}{l}98 \\
01)^{*}\end{array}$ & $(<0$ & 07 \\
\hline
\end{tabular}

$X^{2}:$ Chi square test

MCP: P for Monte Carlo test

T: Student t-test

$t_{1}$ : Paired t-test between before the program and other periods.

$t_{2}$ : Paired $t$-test between immediately after the program and three month later.

*: Statistically significant at $P<0.05$. 
Table (7): Self-efficacy of the male and female osteoarthritic elderly patients before and after implementation of the self-care program (immediate and three months later)

\begin{tabular}{|c|c|c|c|c|c|c|c|c|c|c|c|c|}
\hline \multirow{3}{*}{ Self-efficacy Levels } & \multicolumn{4}{|c|}{ Before the Program } & \multicolumn{4}{|c|}{$\begin{array}{c}\text { Immediately after the } \\
\text { Program }\end{array}$} & \multicolumn{4}{|c|}{ Three Months Later } \\
\hline & \multicolumn{2}{|c|}{$\begin{array}{c}\text { Male } \\
(\mathrm{n}=18)\end{array}$} & \multicolumn{2}{|c|}{$\begin{array}{c}\text { Female } \\
(\mathbf{n}=24)\end{array}$} & \multicolumn{2}{|c|}{$\begin{array}{c}\text { Male } \\
(n=18)\end{array}$} & \multicolumn{2}{|c|}{$\begin{array}{c}\text { Female } \\
(\mathbf{n}=24)\end{array}$} & \multicolumn{2}{|c|}{$\begin{array}{c}\text { Male } \\
(\mathrm{n}=18)\end{array}$} & \multicolumn{2}{|c|}{$\begin{array}{c}\text { Female } \\
(n=24)\end{array}$} \\
\hline & No & $\%$ & No & $\%$ & No & $\%$ & No & $\%$ & No & $\%$ & No & $\%$ \\
\hline Low self-efficacy & 6 & 33.3 & 13 & 54.2 & 2 & 11.1 & 1 & 4.2 & 2 & 11.1 & 2 & 8.3 \\
\hline \begin{tabular}{|l|} 
Moderate self-efficacy \\
\end{tabular} & 9 & 50.0 & 9 & 37.5 & 7 & 38.9 & 18 & 75.0 & 10 & 55.6 & 19 & 79.2 \\
\hline \begin{tabular}{|l|} 
High self-efficacy \\
\end{tabular} & 3 & 16.7 & 2 & 8.3 & 9 & 50.0 & 5 & 20.8 & 6 & 33.3 & 3 & 12.5 \\
\hline Test of sig. & \multicolumn{4}{|c|}{$\mathrm{X}_{2}=7.009, \mathrm{P}=0.036^{*}$} & \multicolumn{4}{|c|}{$\mathrm{MCP}=0.043^{*}$} & \multicolumn{4}{|c|}{$\mathrm{MCP}=0.036^{*}$} \\
\hline Mean \pm SD & \multicolumn{2}{|c|}{$181+041$} & \multicolumn{2}{|c|}{$1.59 \pm 0.39$} & \multicolumn{2}{|c|}{$9 \pm 0.36$} & \multirow{2}{*}{\multicolumn{2}{|c|}{$\begin{array}{l}2.04 \pm \\
.143)\end{array}$}} & \multicolumn{2}{|c|}{$2.0 \pm 0.31$} & \multicolumn{2}{|c|}{$1.85 \pm$} \\
\hline $\mathbf{t}(\mathbf{P})$ & \multicolumn{4}{|c|}{$2.103(0.041)^{*}$} & \multicolumn{2}{|c|}{$1.544(0.143)$} & & & \multicolumn{4}{|c|}{$2.563(0.012)$} \\
\hline $\mathbf{t}_{1}(\mathbf{P})$ & & & & & \multicolumn{2}{|c|}{$\begin{array}{c}10.733 \\
(<0.001)^{*}\end{array}$} & \multicolumn{2}{|c|}{$\begin{array}{c}12.66 \\
(<0.001)^{*}\end{array}$} & \multicolumn{2}{|c|}{$\begin{array}{c}6.503 \\
(<0.001)^{*}\end{array}$} & \multicolumn{2}{|c|}{$\begin{array}{c}6.787 \\
(<0.001)^{*}\end{array}$} \\
\hline $\mathbf{t}_{\mathbf{2}}(\mathbf{P})$ & & & & & & & & & & 63 & & 18 \\
\hline
\end{tabular}

$X^{2}$ : Chi square test

MCP: P for Monte Carlo test

T: Student t-test

$t_{1}:$ Paired $t$-test between before the program and other periods.

$t_{2}$ : Paired t-test between immediately after the program and three month later.

*: Statistically significant at $P<0.05$.

\section{DISCUSSION:}

Illiteracy was prevailing $(40.5 \%)$ of the present study sample (table 1). It is attributed to the fact that illiterate elders don't simply expect improvement and consider their disease and its related stressors as an expected part of aging, and others are seldom practice healthy practices. Adversely, highly educated elders are welcomed to use more advanced practices and be educated about different lines of treatment which has proven to subside greatly their stressors to satisfactory degree. This result is support by Unicef Egypt statistics, Walsh (2010) who mentioned that total adult illiteracy in Egypt represents (66\%) from 2005 - 2010. According to the Centers for Disease Control and Prevention (2005), which reports that level of patients' education is correlated with the incidence of knee osteoarthritis. Incidence of knee OA in people with less than 8 years of the current study revealed that illiterate patients formed the greatest proportion of the sample. This could be attributed to the fact that lack of education and prevention knowledge can make people more risky to be exposed to diseases. A part of ineffective self- care management of OA in elderly residents is related to their literacy level,(Rogers et al., 2005). Education was $44 \%$ while in those who received $9-11$ years was $41 \%$ and in people receiving high school education was 36\%,(CDC, 2005).

The present study revealed that elders perceived exercise to crate disease progression, believe about the ineffectiveness of exercise, and lack of knowledge about type of exercise (table 2). The present study also revealed that males comply more frequently with exercise compared to females. According to the British National Institute for Health and Clinical Excellence, (2008) perceived barriers to compliance with late 
life exercise among elders with OA typically take the form of perceived physical, psychological, social risks, or other concerns. The physical risks include fear of injury, over exertion, and aggravation of joint pain, muscle soreness, or excessive fatigue. Psychological concerns were the elders' perceptions that exercise is either a waste of time, too difficult to perform, or cannot be maintained. Examples of the social barriers include having no time, or no peer or family support and lack of appropriate equipment or clothing. Other concerns were inconvenience of activity and non-acquaintance with the type of exercise, (Oesch et al., 2009). This may be planned by the fact that exercise is principally an energetic activity that requires high level of effort and skill that may be harder to fulfill as female people reach advanced age in addition, exercise calls for appropriate supervision, guidance and supportive training which lack in institutions.

The present study reflects that half of the elderly patients were compliant with the dietary management (table 3). These comparable with the hypothesis that changing eating habits is usually useful for eldersespecially those with OA either males or females and a main cause of non-compliance in many literatures ,(Musumeci et al., 2015). Developing healthy eating habits is important for elders with OA. This not only gives elders more energy and endurance to carry out their physical and social activities, but makes them feel more in control of their disease,(Sanghi et al., 2015). Low intake of vitamin D and vitamin $\mathrm{C}$ is possible risk factor for OA, while certain food groups, such as milk and dairy products, meat and poultry are beneficial for know OA. Thus, we could affirm that nutritional imbalance may be involved in the pathogenesis of OA, While food alone does not prevent OA, eating well can help manage symptoms and prevent complications. Healthy means making healthful food choices the majority of the time, making healthful food choices the majority of the time, preparing food in different ways, and eating in moderation, (Eymard et al., 2015).

Daily stressors are the routine challenges of day-to-day living, and although they may be relatively minor, they are tangible events that can have immediate negative impacts on physical and psychological well-being (Almeida, 2005; Shevaun et al., 2007). The results of the current study revealed a significant difference between males and females in difficulties in carrying out ADL and pain experiencing stressors (table4). A study carried out in Haiti by Redman (2007) stated that osteoarthritic older men reported less stressor from their daily activities than did older women. On the other hand, osteoarthritic women had more chronic stressors related to social and family issues them did men.These finding matches with, Pope (2008) reported that, $40 \%$ of arthritis patients said that they cannot do, or it is very difficult to do, at least one of nine important activities of daily living. Such deterioration and impairment interferes with their ability to work, function in their community, and care for their family. Besides the impact of pain and disability. OA often has a negative impact on other aspects of lifestyle, causing depression, anxiety, failing of helplessness and difficulty taking part in every day personal and family activities and responsibilities. 
The program portrayed in the current study succeeded in increasing skills performance and self-care practices of the osteoarthritic elderly patients as evidenced by improvement in their functional abilities, depressed mood, self-efficacy, and disease related stressors post self- care program (table 4, 5, 6, 7). It emphasizes that gerontological nurse needs to perform continuous assessment toward understanding how osteoarthritis alter elder's ability to perform daily tasks, social wellbeing, psychological functioning, daily stressors as well as elder's confidence to practice selfcare activitiesand the demands associated with independent living (i.e., adherence to the prescribed therapeutic regimen).

This study argue in favor of other researches in Alexandria (Saad et al., 2015), Sweden (Carina et al., 2014), and China, (Huang, 2014). Which have demonstrated that osteoarthritis affects various aspects of daily life and creates numerous sources of physical and emotional stressors. These may include living with uncertainty, reduced energy, loss of functional ability, pain, mobility problems, difficulties in self- care, threats to self- esteem, socioeconomic burden, diminished independency, and reduced involvement in family.

Because of the chronic nature of their condition elder with OA must learn to manage and cope with stressed on a day to day basis through self- care,(Osborne et al., 2006; Arokoski 2005; Dieppe et al. 2008) who stated that, patient teaching is one of the primary therapeutic approaches to OA, has been shown to be helpful in the selfmanagement; they require the skills, knowledge and motivation to effectively manage their day to day health needs. Access to information, techniques and social support is vital. Research suggests that, patient teaching is feasible and valuable for achieving improvements in quality of life in function, wellbeing an improved coping. Teaching and reassurance for the patient, their family, and caregivers is recognized as an important component of OA therapy. It is important to understand the benefits of taking an active role in the management of their disease.

The results of the current study revealed a significant improvement in all disease related stressors suffered by osteoarthritic elders after conducting a 12- session selfcare management (table 4, 5, 6, 7). A Dutch study, Riemsma et al. (2009) showed an improvement in lifestyle and quality of life in 330 arthritic elders after a 13- session medical self- care educational intervention. In support to their forgoing a quasi experimental research induced in the Rheumatology and Rehabilitation Department and out-patient clinic of Minia university, hospital, Egypt, Abd El-Khalik et al. (2014), documented that there was a significant improvement in osteoarthritic patients, knowledge and self- care practices after participation in an instruction scheme compared to those who didn't participate as regards knowledge related to the disease and its treatment modalities. 


\section{CONCLUSION:}

Based on the results of the present study and research hypotheses, it can concluded that the findings revealed that the implementation of the self-care program for osteoarthritic elders is associated with significant improvements in their functional abilities, depressed mood, and self- efficacy. The program also succeeded in improving elders' self-care practices which in turn, has a positive effect in all disease related stressors such as difficulties in carrying out activity of daily living, pain, limitation in mobility, helplessness and dependency on others.However, these observed positive improvements decreased gradually as time lapses which indicates the need to reinforce, motivate and encourage elders to maintain their functional in order to reach the ultimate goal toward independence.

\section{RECOMMENDATIONS:}

In order to improve self-care of the osteoarthritic elderly patients, the following recommendation are suggested:

1. A better understanding of $\mathrm{OA}$ through patient education program including its causes, clinical features, pharmacological and non- pharmacological methods are requisite to the alleviation of stressors accompanying the disease process and increased self- efficacy among elderly residents.

2. Current recommendations for the accumulation of 30 minutes of moderate physical activity on most days of the week provide feasible and effective intervention for persons with OA. Exercise therapy should begin in early stages of the disease and maintain for longer periods. However, as soon as, exercise stops, the benefits are lost making it imperative to maintain habitual exercise, therefore, recommendations for compliance is very important. Not only is there a need for adequate fluency in exercise, but also for the maintenance of sufficient intensity level. For each patient, there must be an acceptable range of activity that will achieve the desired results without deterious effect.

\section{The Results raised many Questions that form a Template for Future Research:}

1. Further study is needed to examine methods to improve exercise self- efficacy in people with OA. Further research into the area of motivation to exercise and the formation of an exercise habit in patient with OA could be highly beneficial.

2. Further research which describes the negative impacts of disability on quality of life and elucidates elders' characteristics, resources and coping strategies which promote successful psychological adjustment is needed. 


\section{REFERENCES:}

Abd El-Khalik E., Mohamed W., El-Labban A., Teleb S. and Gamal L. (2014):Impact of designed teaching program on osteoarthritis patients' outcome at Minia university hospital, medical surgical nursing, faculty of nursing, Minia University, Egypt. Nat Sci; 12(7): 30 - 39. Available at: Http://www.sciencepub.net/nature

Almeida DM. (2005): Resilience and vulnerability to daily stressors assessed via diary methods. Current directions in psychological science, 14, $64-68$.

Arokoski JP. (2005): Physical therapy and rehabilitation programs in the management of hip osteoarthritis. Euramedicophys Jun; 41(2): 155 - 61 .

British National Institute for Health and Clinical Excellence, (2008): Osteoarthritis national clinical guidelines for care ad management in adults. London. NICE. www.nice.org.uk/cg59.

Carina A. Garellick G. Rystedt H. and Dahlberg L. (2014): Better management of patients with osteoarthritis: development and nationwide implementation of an evidence based supported osteoarthritis self management program. Department of clinical neuroscience and physiology, sahlgrenska academy, University of Gothenburg, Sweden Wiley online library, DOI: 10: 1002 /msc1085.

Carol M. (2012): Assessing for risk and progression of osteoarthritis. The nurses' role.AJN, American journal of nursing, march, vol 112. Issue 3, P. 526 - 531.

Centers for Disease Control and Prevention (2008): National Center for Chronic Disease Prevention and Health Promotion. Arthritis basics, risk factors. Available at: Http://www.cdc.gov/arthitis/arthitis/ risk_factors.htm.

Cook C., Pietrobon R. and Hegedus E. (2007): Osteoarthritis and the impact on quality of life health indicators int; 27 (4): 315 - 21.

Dieppe P., Brandi and Klippel JH. (2008): Osteoarthritis, clinical features, pathology and pathogenesis: treatment primer on the rheumatic diseases. $13^{\text {th }}$ ed., New York Springer science and business media LLC: $224-40$.

Eymard F., parsons C., Edwards MH., Petit Dop F., Reginster JY., Bruyere O., Richette P., Cooper C. and Chevalier X. (2015): Diabetes is a risk factor for knee osteoarthritis progression. Osteoarthritis.Cartil DOI: 10.1016 / j.joca. 2015.01.013.

Fries JF., Spitz P., Kraines R. and Holman H. (1980): Measurement of Patient Outcome in Arthritis Rheum;23(2)137-45. 
Gignac MA., Davis AM., Hawker G., Wright JG., Mohamed M. and Fortin PR. (2006): What do you expect? You are just getting older. A comparison of perceived osteoarthritis - related and aging related health experiences in middle and older age adults. Arthritis rheum; 55(6): $905-12$.

Huang Y., Thaniwattananon P. and Kritpracha C. (2014): pain and pain management in elderly with knee osteoarthritis in china. Faculty of nursing, prince of Sangkla University, Thailand, Singklanagarind.Journal of nursing.Vol 34: 25 - 34

Lorig K., Brown B., Ung E., Chastain R., Shoor S. and Holman H. (1989): Development and Evaluation of a Scale to Measure the Perceived Self-Efficacy of people with Arthritis .Arthritis and Rheumatism; 32(1): 37-44.

Musumeci G., Szychlinksa MA. andMobasheri A. (2015): Age related degeneration of articular cartilage in the pathogenesis of osteoarthritis: Molecular markers of senescent chondrocytes. Histol.Histopathol, 30, $1-12$.

Newman S., Steed L. and Mulligan K. (2005): Self-management intervention for chronic illness. Lancet; 364: 1523 - 37.

NHS (2008): Evidence on the experience and perception of people with arthritis. National institute for health and clinical excellence.

Oesch RR. And Bachmann S. (2009): Introduction to physical medicine and rehabilitation. In GS firestein et al. Kelley's textbook of rheumatology $8^{\text {th }}$ ed., Philadelphia: Saunders Elsevier (1): 1023 - 33.

Osborne RH., Spinks JM. and Wicks IP. (2006): Patient education and self management programs in arthritis. Med J Aust, 180: S23-S6.

Pope R., Rudxinski M. and Whitaker A. (2008): Supporting patient self care for osteoarthritis from the American pharmacies association and the American academy if physician assistants.

Radloff LS. (1977): The CES-D scale: A Self-Report Depression Scale for Research in the General Population .Applied Psychological Measurement; 1(4):385-401.

Redman BK. (2007): Accountability for patient self management of chronic conditions; ethical analysis and a proposal. Chronic illness; 3: 88 - 95 .

Riemsma RP., Kirwan JR., and Taal E. (2009): Patient education for adults with rheumatoid arthritis. Cochrane database syst Rev (2): CD 003688. 
Saad A., ElShatby A. and Sofar S. (2015): Effect of a physical training program of the functional health status among patients with knee osteoarthritis. Medical Surgical Nursing Department, Faculty of Nursing, Alexandria University, Egypt. Journal of American Science, 11(4): 96 - 109.

Sanghi D., Mishra A., Sharma AC., Raj S., Mishra, R., Kumari R., Natu SM., Agarwal S. and Srivastava RN. (2015): Elucidation of dietary risk factors in osteoarthritis knee a case control study J. Am. Coll. Nutr. 34, 15 - 20.

Shevaun D., Almeida D. and Charles S. (2007): Age differences in reactivity to daily stressors: the role of personal control. Department of Psychology. North Carolina State University. Journal of gerontology, psychological sciences.Vol 62B. No 4, P. 216 225.

Smeltzer S., Bare B. and Hinkle J. (2008): Cheever Brunner and Suddarth's textbook of medical surgical nursing. $11^{\text {th }}$ ed., Philadelphia: Lippincott Williams and Wilkins Company; P.p. $1914-16,174-85$.

Walsh H. (2010): Unicef Egypt statistics. Available at: Http://www.unicef.org/infobycountry/egypt_statistics.html.

Waltz C., Strickland O. and Lenz E. (1991): Measurement in Nursing Research. $3^{\text {rd }}$ ed. Philadelphia: FA Davis Company.

Wesseling J., Welsing PM., Bierma-Zeinstra SM. Dekker J., Gorter KJ. And Kloppenburg M. (2013): Impact of self reported comorbidity on physical and mental health status in early symptomatic osteoarthritis: the check (Cohort Hip and Cohort Knee), study rheumatology (oxford), Jan 52(1): 180-8. 
برنـامـج العناية الذاتية لتحسين الضغوط اليوميـة المصاحبة لمرضى خشـونـة المفاصل نزلاء دور المسـنيـن بمدينـة بـورسـعيد

\author{
أ.ـ.نوال محمود سليمان، ا.ـ حسن على عبد الواحد، د.رضا ابراهيم الموافى، د. أمبية محد العالم، فاطمة \\ محمد محمد السويركى

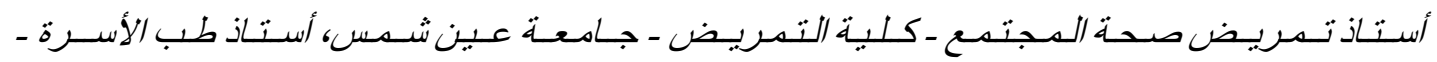

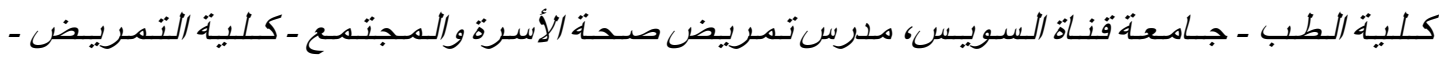

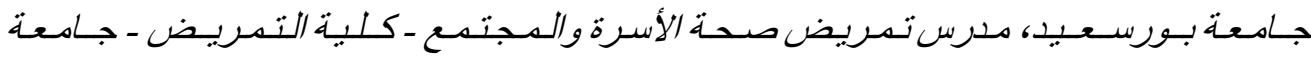

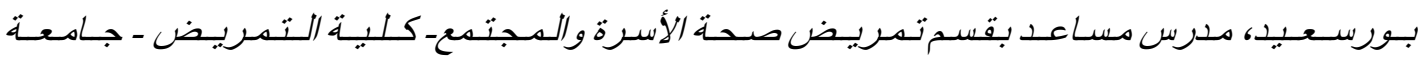 \\ بورسعبد.
}

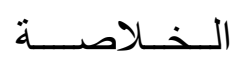

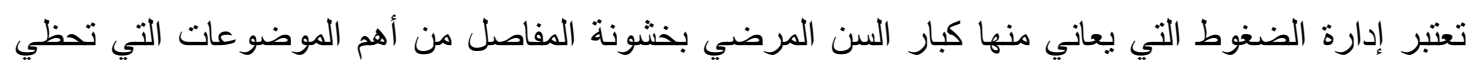

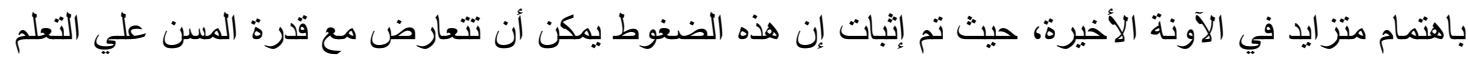

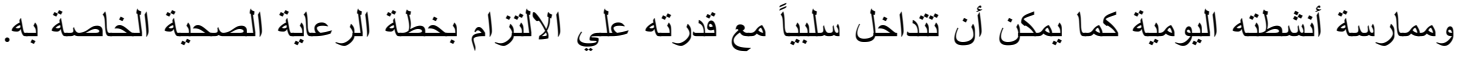

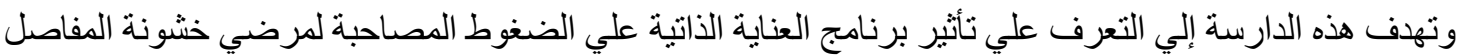

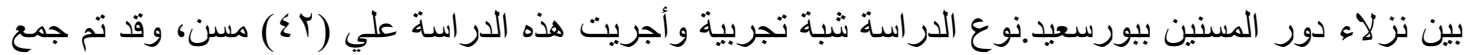

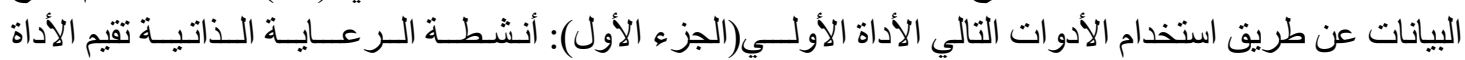

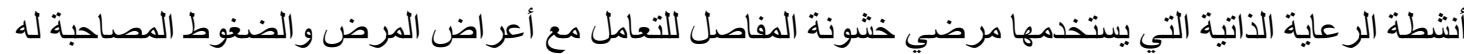

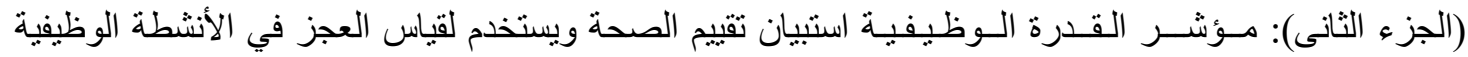

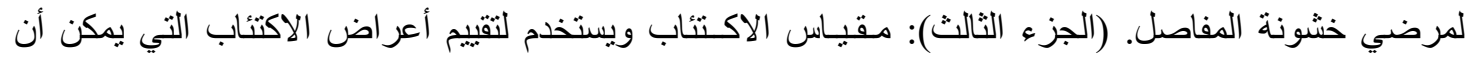

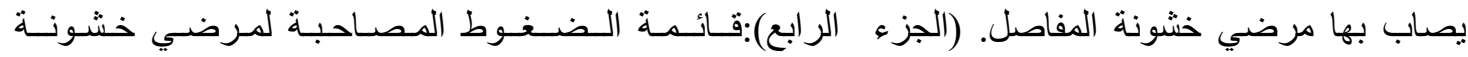

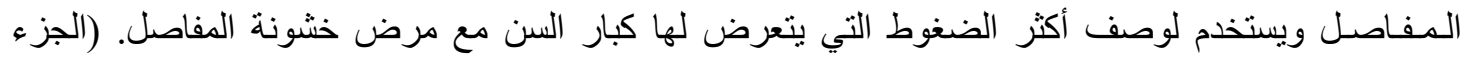

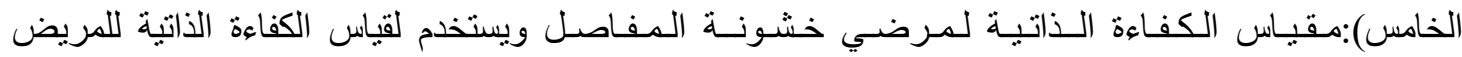

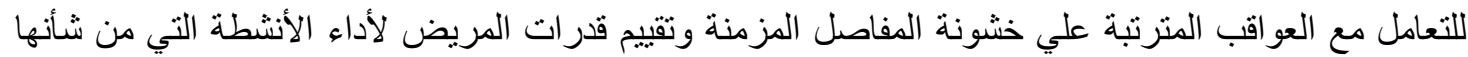

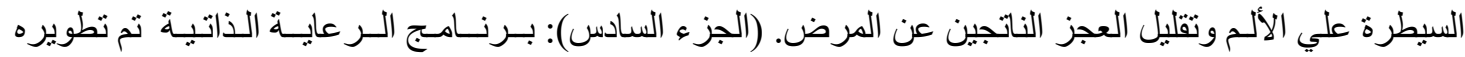

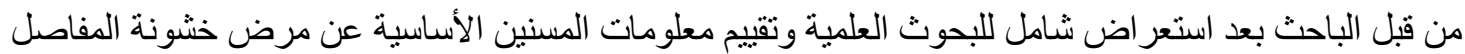

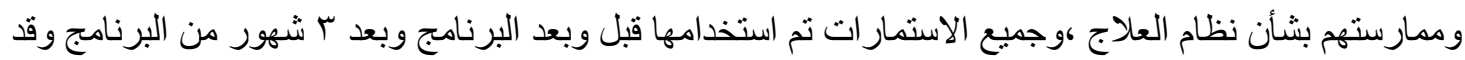

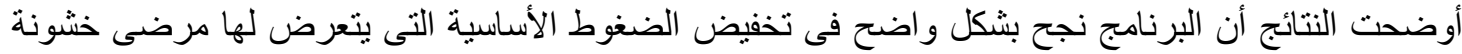

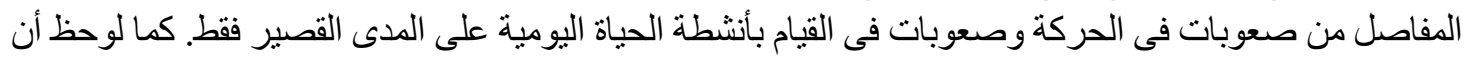

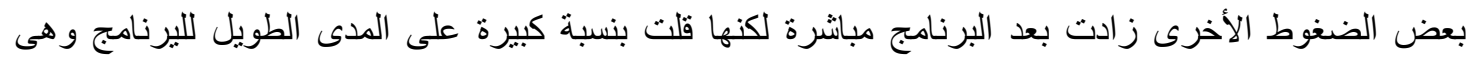

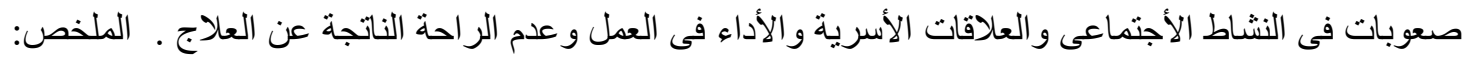

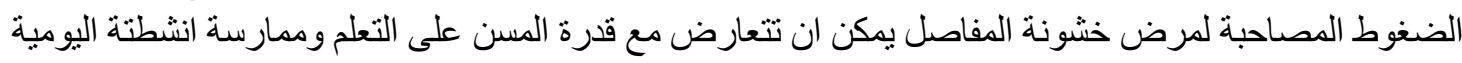

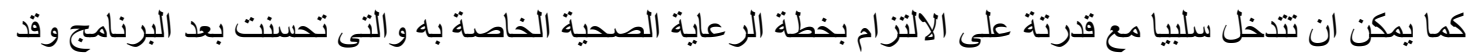

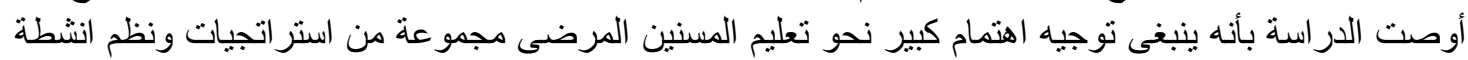

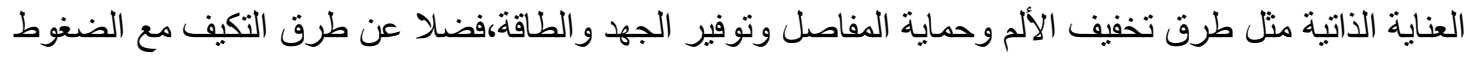
النفسية للمرض وتحسين قدرتهم على القيام بأنشطة الحياة اليومية.

الكلمات المرشدة: خشونة المفاصل ،كبار السن، برنامج العناية الذاتبة، أنشطة الحياة اليومي 